\title{
EUROPEAN UNION BETWEEN THE CENTRALIZATION AND DECENTRALIZATION RHETORIC. BRIEF CONSIDERATION UPON THE EVOLUTION AND PERSPECTIVE OF THE “GOVERNANCE” EUROPEAN MODEL ${ }^{1}$
}

\section{Mătuşescu}

\section{Constanța Mătuşescu}

Faculty of Law and Social-Political Sciences, Social-Political Sciences Department

"Valachia" University of Târgovi $\square$ te, Romania

Correspondence: Constan $\square$ a Mătu $\square$ escu, Universitatea Valahia din Târgovi $\square$ te, B-dul Regele Carol I, nr. 2, Târgovi $\square$ te, Dâmbovi $\square$ a, Romania

E-mail: constanta_matusescu@yahoo.com

\section{Abstract:}

The paper intend to achieve s brief incursion in the European model of the governance on several levels, seen as an instrument of national public administration Europeanization.

Keywords: European Union, multilevel governance, decentralization, subnational authorities.

\section{Introduction}

European Union represents today a laboratory to produce new legal instruments and governance techniques, created at the interlocking of the treaties. Innovations do not cover mainly the nature of the public issues, but the instruments chosen to solve them. The role of these concrete instruments of public action is to contribute to the improvement of the European political system functioning. Thus, we are witnessing in recent decades, to an evolution of the European political system toward a greater flexibility: more flexible coordination; emergence of numerous control mechanisms with alternate character; proliferation of new types of public instruments less restrictive for the Member States than the standard tools of the Community method (regulations, directives); is given a more and more important place to the consultations and deliberations; the institutional system become more and more complex, creating multiple independent structures; cross logic is constantly developing; it is given a central place to define the common objectives and the accent is rather on methods and forms of public action, instead on the content of the action.

Appealing to this type of instruments it is not only the exclusive privilege of the European Union. Similar mechanisms were developed in the majority of the Western states (even in areas where not directly related with the European integration), and the international right level. The flexibility is preferred to the traditional "dirigisme" approach, creating a "new public management", ${ }^{2}$ characterized, among other things, by closer links

\footnotetext{
${ }^{1}$ This work was supported by CNCSIS-UEFISCSU, project number PN II-RU, code 129, contract 28/2010.

${ }^{2}$ H. Christopher, A Public Management for All Seasons? in Public Administration, Vol. 69, 1991.
} 
between the private and the public sectors, openness toward the civil society and seeking solutions to technical rather than political solutions to contemporary issues ${ }^{3}$.

In the context of this paradigm shift, the territorial factor becomes an essential one. The territories are not passive receptacles of the European Union anymore, but they become actors that provide legitimacy to the system, allowing the interests' conjunction at European level, committed to move close to its base. Is there a real just return? Do these new European governance instruments contribute to the empowerment of the territorial actors and to the increasing of their role in the decisional process? Here are some reflections paths that we are willing to approach, starting from the multilevel governance model, which is used today to describe the functioning of the European Union.

The need to overcome the "Community method" and the conceptualization of the "governance model" at EU level.

The impossibility for the European institutions to administrate alone Europe and extraordinary diversity of the political administrative realities at the level of the Member States determined the Union to totally rethink the public action, overcoming the traditional Community method, based on the decisional triangle: Council - Commission - European Parliament and heading toward other actors - the subnational authorities of the Member States, civil society, private bodies, that tried to associate them to the European decisional process. Concerning the appeal to the local and regional actors, Europe and subnational structures constitute, as remarked in doctrines ${ }^{4}$, "two separately designed worlds" and that have evolved separately till, being aware of their interests convergence, have developed bridges between supranational echelon and the local one. If the Community institutions discovered progressively the advantages of the dialogue with the subnational entities of the Member States and of an articulation of the Community policy on local realities, the regional and local authorities understood rapidly the earnings that can be obtained from an active presence in the European institutions and from an effective participation to define and achieve the Community policies, earnings found also in the strengthen of their position inside the Member States. Thus, the supranational and subnational institutions tried to mutually consolidate, and the Union furnished a political space where the territories can manifest and promote their interests.

Without favoring directly and with undeniable evidence, the spreading of the decentralization and local autonomy principles in the Member States, the European Union conceptualized progressively, under pre pressure determined by the increase of the territorial complexity, multiplication of the decision levels and transformations of the world economic system, a model of European "governance" as a solution to coordinate different actors and

\footnotetext{
${ }^{3}$ L. Boussaguet, S. Jacquot, Les nouveaux modes de gouvernance: quelle nouveauté pour quelle gouvernance? in R. Dehousse, (coord.), Les politiques européennes, Presses de Sciences-politique, Paris, 2009, p. 410.

${ }^{4}$ I. Janin, J. Palard, Les collectivités territoriales et l'Europe, in Décentralisation, Etat et territoires, Cahiers français $\mathrm{N}^{\circ} 318$, La Documentation française, 2004, pp. 44-51.

5 The term "governance" is used for the first time in a report of the World Bank from 1989, regarding the economic development of African States where, starting from the existence of a "government crises" is found the need of a new way of exercising of power, of a new governing system, based on new principles and relations between the national states and international bodies, civil societies, companies and multinational corporations that lead to a better management of the businesses - Adrian Liviu Ivan, Perspective teoretice ale construcției europene, Cluj-Napoca, Ed. Eikon, 2003, p. 266.
} 


\section{EUROPEAN UNION BETWEEN THE CENTRALIZATION AND DECENTRALIZATION RHETORIC. BRIEF CONSIDERATION UPON THE EVOLUTION AND PERSPECTIVE OF THE “GOVERNANCE” EUROPEAN MODEL}

different decisional level ${ }^{6}$. Polysemantic ${ }^{7}$ concept, the governance essentially assumes, opposing the traditional governance concept, hierarchical and centralized, the flexible way to govern through the coordination of a plurality of private and public actors, based on negotiation and consensus. Governance provides to the Union instruments updated to European construction, in order to guarantee the effectiveness of its action, but also new sources of legitimacy, through a more and more association of the local level to the European integration process ${ }^{8}$.

\section{Partnership, subsidiarity, proximity - fundaments of the multilevel governance}

The partnership principle, introduced with the reform of the structural funds, operated in 1988, evolved toward the idea of a "strengthen cooperation" when modified in 2006 , opened the path to a new way of action at Community level, that presume the subnational authorities association in every phase of implementation of these financial instruments, from programming till evaluation. This allowed the development of new echelons in decision making and the implementation of the funds, creating a new issue at Community level - that of multilevel governance ${ }^{10}$, where the local entities participating in the implementation of the funds represents a third level of governance. Based on an active concertation of all categories of interests' existent at the Union level, the Commission activity usually falls in this logic of multilevel governance.

Searching the territorial coherence, the Commission developed a "consultative administration" ", named comitology, in which groups of local and national experts, and also representatives of different categories of private interests participate in decision making. Also, due to the lack of own territorial administration, there are involved subnational authorities in the implementation of the European legislation and Union' policies, thus offering conventional instruments, focused on objectives, like the tripartite contracts between Union, state and local authorities ${ }^{12}$. Implementing various techniques of consultation, taking into account the expertise of various actors, the Commission encouraged the decentralization in the implementation and control of the Community rules, which allowed the interconnection of the national and European echelon.

\footnotetext{
${ }^{6}$ This model start from the concept of corporate governance appeared in 1970 in the private sector, which designed a new way of company management, based on an articulation between the shareholders and the executive powers.

7 To analyze the evolution of the governance concept and its various dimensions, see Jean Pierre Gaudin, Pourquoi la gouvernance? Presses de Sciences Po, 2002; Marcou Gérard, La gouvernance: innovation conceptuelle ou artifice de présentation?, in La gouvernance territoriale, Annuaire des collectivités locales, 2006.

${ }^{8}$ To argument the need of a "governance perspective" at the European Union level see H. Wallace, W. Wallace, A. Pollack, Elaborarea politicilor in Uniunea Europeana, Bucharest, European Institute of Romania, $\mathrm{V}^{\text {th }}$ edition, 2006.

${ }^{9}$ According with the Council Regulation no. 1083/2006 from 11 July 2006, art. 11 §.1, "The objectives of the funds are followed in close cooperation (hereinafter "partnership") between the Commission and each Member State" (JO L 210, 31.7.2006, p. 25).

${ }^{10}$ The paternity of this expression is attributed to Gary Marks, that starts from the observation that regional policy is no longer based on traditional model of governance, to identify the new system of "continuous negotiations between govern and various territorial levels" - G. Marks, Structural Policy in the European Community, in Alberta Sbragia, ed., Europolitics: Institutions and Policy Making in the 'New' European Community, The Brookings Institution, Washington D.C., 1992, pp. 191-224. Regarding the scientific debate concerning this concept, see Ian Bache, Multilevel Governance and European Union Regional Policy, in I. Bache, M. V. Flinders, Multilevel Governance, Oxford University Press, Oxford, 2004, pp. 165-178.

${ }^{11}$ C. Blumann, Comitologie et administration indirecte, in J. D. de la Rochere (coord), L'execution du droit de l'Union, entre mecanismes communautaires et droits nationaux, Ed. Bruylant, 2009, p. 139.

${ }^{12}$ Commission Communication "A framework for target-based tripartite contracts and agreements between the Community, Member States and regional and local authorities", COM (2002) 709 from 11 December 2002.
} 
Another illustration of the multilevel governance is represented by the "open method of coordination - OMC" established thorough Lisbon Strategy. This concerns the exercise of an European influence upon the Member States policies in the area of the competencies assigned by the Union through treaties, paving the way to common actions that are not limited by assigned competencies and allowing the exchange of good practice between national administrations located at different levels of decision making ${ }^{13}$. Concretely, the clerks on different echelon of the subnational authorities are invited by Union to make known their working methods, and also different programs they are developing on territorial level.

The development at Union level of the governance theory was, in a certain way, contradicted by the enrollment in the treaties of a mechanistic model for the regulation of the competencies, based on a vertical division of the powers - the subsidiarity principle ${ }^{14}$. Due to the evolution of the integration the Union began to cover more and more areas that interfered with the states' competencies or with the subnational entities, and appeared the need to define the relationships between the level of European authority, national and local, to rethink the territorial repartition of the competencies in Europe. The subsidiarity principle, with federal origin and old philosophical and political roots ${ }^{15}$ was described in the Maastricht Treaty (art. 3-B) as general principle of exercising the divided competencies between the Union and the Member States ${ }^{16}$, establishing the pertinent level for decision making: either at Community level, or at national level. Although, in essence, both the partnership principle and the subsidiarity one concern the same objective - the action efficiency, the subsidiarity was interpreted for a long time in an ascendant way, as a mean of intervention of the superior echelon when the inferior level is weak. In the treaty logic, that required the decisions to be taken as near as possible to the citizens (art. A par. 2 TUE), the subnational entities could also be concerned by the subsidiarity principle, as the nearest authorities to the citizens; this principle functioned exclusively in favor of states. Being afraid of a potential interference of the Union in the allocation of the competencies at internal level, the states did not accept such an interpretation of the principle, and the Union, obliged to respect the internal organization of the Member States, was forced to accept the state filter upon the pertinence of an action achieved locally. This leads, in practice, to not expand the subsidiarity principle at local levels, even after the supplementary clarifications brought by Nice and Amsterdam Treaties, that introduced like appreciation criteria of the pertinent level of decision the effectiveness and the added value of the action. The criteria introduced did not favor the interpretation in sense of the proximity of the subsidiarity principle, because the nearest level to the citizen is not necessarily the most appropriate, and that brings a greater effectiveness and added value. Finally, the subsidiarity contributed to ensure the relegitimation of the state inside the European Union.

More and more fervent arguments in favor of an interpretation of subsidiarity principle closer to the proximity principle written in the treaties has come amid deepening the debate on the democratic deficit suffered by the Union. Even if the subsidiarity is a principle that concerns the action effectiveness and not the democratic legitimacy, amid the claims of the federal states ${ }^{17}$, on one hand and the Regions Committee, on the other hand, begins a new

\footnotetext{
${ }^{13}$ To analyze this method of governance see R. Dehousse (coord.), L'Europe sans Bruxelles: une analyze de la méthode ouverte de coordination, Paris, L'Harmattan, 2004.

${ }^{14}$ N. Levrat, L'Europe et ses collectivités territoriales. Réflexions sur l'organisation et l'exercice du pouvoir dans un monde globalisé, Bruxelles, PIE-Peter Lang, 2005, pp. 288-291.

${ }^{15}$ See Jean Louis Clergerie, Le principe de subsidiarité, Editions Ellipses, 1997; Frédéric Baudin Cuilliere, Principe de subsidiarité et bonne administration, LGDJ, Paris, 1995, p. 8.

${ }^{16}$ După o primă consacrare a acestuia in Actul Unic European, dar numai in ceea ce prive $\square$ te ac $\square$ iunile in favoarea mediului.

${ }^{17}$ Acestea considerau că aplicarea strictă a principiului neagă specificită $\square$ ile lor constitu $\square$ ionale, determinând o recentralizare a competen $\square$ elor.
} 


\section{EUROPEAN UNION BETWEEN THE CENTRALIZATION AND DECENTRALIZATION RHETORIC. BRIEF CONSIDERATION UPON THE EVOLUTION AND PERSPECTIVE OF THE “GOVERNANCE” EUROPEAN MODEL}

valence of the subsidiarity principle, that of instrument in the service of the democratization of the European Union, bringing the decision closer to the citizen.

Starting from this democratized version of subsidiarity, of its conjugation with proximity, the Lisbon Treaty integrated explicitly the local and regional authorities from the Member States in the area of implementation of the subsidiarity principle, and to guarantee its effectiveness, provide new mechanisms thorough which the subnational entities (represented at the level of Region Committee) to supervise the process of nearness of the decision to the citizen, depending by the internal organization of the state, by the competencies they have in the national legislation and by the existent mechanisms to be taken into consideration in the process prior to decision adoption. They cannot pretend therefore an automatic right to be associated.

The institutionalization of the partnership, the joint interpretation of the subsidiarity and proximity beside the citizen and the more and more powerful involvement of the subnational actors in the European decisional process, through a permanent structural dialogue with European institutions had as a consequence a "de-verticalization" effect in the general organization of powers inside the European Union between the third level of public intervention: local, national and communitarian ${ }^{18}$. Thus it is proceedings from a hierarchical conception of the power relations to a unilateral and authoritarian logic, to a public action based on a network of public actors (both public and private), based on a continuous negotiation and on a partnership between actors at different levels. In other words, it is developing a model of pluralist governance, based on the interpenetration of different types and political units and loyalties. There isn't only one center of authority, but many, that are interpenetrating and operates on various territories, not necessarily very clear demarcated. The compliance, mainly voluntarily, it is obtained offering incentives ${ }^{19}$. This model, explained through the concept of multilevel governance presumes in fact to conciliate the general interest with the multitude of particular interests. It is credited, among other things, to undrawn a model of an European construction, to not orient the European integration toward a predetermined vision, intergovernmental of supranational ${ }^{20}$.

Union itself is seen as a multilevel governance system. Through the White Paper regarding the European Governance ${ }^{21}$, adopted by the European Commission in 2001, the multilevel governance receive, beyond its strictly analytic function, that allowed to describe a phenomenon of interaction between various decisional level, a normative dimension ${ }^{22}$. Adopted in a context marked by numerous debits concerning the necessity of reforming the operation framework of the European Union to reduce the democratic deficit and to bring the European citizen closer, the White Paper propose a model of public action where the development of the policies is done through the contribution of all social actors, in an interactive environment. The policies are not decided anymore at high level, but in "a virtual circle based on interaction, on networks and participation in all levels, from the policies

\footnotetext{
${ }^{18}$ P. Claret, L'influence de l'integration européenne sur les institutions territoriales des Etats membres, in I. Illessy (coord.), Constitutional Consequences of the EU Membership, University of Pécs, Faculty of Law, Pécs, 2005, p. 110.

19 J. Zielonka, Plurilateral Governance in the Enlarged European Union, JCMS 2007, Volume 45, number 1, pp.187-209

${ }^{20} \mathrm{~N}$. Levrat, Une dynamique multi directionnelle de la gouvernance multi-niveaux, in Les Cahiers du Comité des Régions, Vol. I, 2009, pp. 49-54.

${ }^{21}$ The White Paper of the European Commision regarding the European governance, COM (2001) 428, JOCE nr. C 87/2 from 12 October 2001 .

${ }^{22}$ Fără ca acest termen să fie expres utilizat, principiile teoriei guvernan $\square$ ei multi-nivel reies din numeroasele texte care tratează problema asocierii puterilor regionale and locale la elaborarea and punerea in aplicare a politicilor comunitare - N. Levrat, Une dynamique multi directionnelle de la gouvernance multi-niveaux, op. cit., p. 51 .
} 
definition to their implementation". The Commission defines the governance as representing "rules, processes and behaviors through which are articulated the interests, managed the resources and it is exercised the power in a society", or as "a set of principles and instruments for the decision making process in the context of existence of multiple layers of actors and decidents in EU: the European institutions at Community level, the governs and national parliaments at the Member States level (national), local and regional authorities at subnational level, as well as other actors, groups of private interests, social partners, civil society". The White Paper plot also the modalities through which, in light of this governance, could be improved the Community institutions' functioning. On one hand, it clarifies the notion of "good governance", as representing the "transparent and responsible management of the human, natural, economic and financial resources, toward a fair and sustainable development", governance that is based on the principles of "participation, openness, responsibility, effectiveness, coherence, subsidiarity and proportionality". On the other hand, the Commission commits itself to take concrete measures, such as: improvement and clarification of the European legislation, guides publishing, development of standards and criteria, public debates and development of the code of conduct regarding the dialogue and consultations ${ }^{23}$.

The frequent references to local and regional authorities across the White Paper, the place they are requested to occupy in the new model of action, the Commission commitment to open a systematically dialogue with the European and national associations of the local and regional collectivities to watch the taking into consideration of the regional and local realities and experiences, in the process of political proposals preparation are leading to the idea that the subnational authorities are targeted with priority by the Chart' provisions. Thus it is expected to increase the degree of legitimacy of the European action and the fight against de democratic deficit, but having a better effectiveness.

At a considerable distance in time (2009), the Region Committee adopt its own White Paper concerning the multilevel governance ${ }^{24}$, where the multilevel governance is defined as representing "a coordinated Union action, of the Member States and of the local de regional authorities, based on partnership and aiming the development and implementation of the EU policies. This involves the common responsibility of the authorities in various levels of power and is based on all the legitimacy democratic sources and on the representativity of various involved actors". According with the Region Committee, various levels of power must act in virtue to a "trust agreement", so each part to put in practice common objectives, according with the institutional autonomy principle, and being necessary the orientation of the orientation of the European governance toward an integrated territorial approach, which shall follow an increased coordination of the objectives in developing European strategies, but however accompanied by a real flexibility regarding the means provided to fulfill them ${ }^{25}$. In its vision, the subsidiarity principle and that of the multilevel governance are inseparable: one concerns the various power levels competencies; the other is focused on their interaction.

The ambition of the Region Committee is the achievement of a real culture of multilevel governance in Europe ${ }^{26}$, through the consolidation of the subdiacent fundaments

\footnotetext{
${ }^{23}$ M. Munteanu, Guvernanța europeană şi dinamica formulării politicilor publice in România, in Sfera politicii no. 125, 2006, http://www.sferapoliticii.ro/sfera/125/art06-munteanu.html

${ }^{24}$ The White Chart of the Region Committee regarding the multilevel governance, CdR 89/2009. Recourse to such an instrument, reserved till then to the European Commission, represents the reflection of the Region Committee ambition to begin an institution on the same level with the Commission - A. Noureau, op. cit., p. 598.

${ }^{25}$ Consulting Report regarding the White Chart of the Regions regarding the multilevel governance, CdR 25/2010, at: http://www.cor.europa.eu/governance.

${ }^{26}$ See the Regions Committee Resolution regarding the political priorities for 2011 (CdR 361/2010 fin), where is written that "it has the intention to continue to develop an European culture of the multilevel governance (GMN)
} 


\section{EUROPEAN UNION BETWEEN THE CENTRALIZATION AND DECENTRALIZATION RHETORIC. BRIEF CONSIDERATION UPON THE EVOLUTION AND PERSPECTIVE OF THE “GOVERNANCE” EUROPEAN MODEL}

and principles inside the European and national political and institutional framework. Its political project includes the adoption of a European Union Chart regarding multilevel governance, which shall help the inclusion among the European values of a common perception of the European governance ${ }^{27}$.

\section{Conclusions}

Although some critics subsist mainly related to the ambiguity of the governance concept, of the strong fragmentation of the European public action resulted from the multiplication of the governance levels, that makes each echelon to have a bigger and bigger part in a diluted global power ${ }^{28}$, the multilevel governance represents the model on which is presently based the political system of the European Union ${ }^{29}$. This shows, according to the doctrine, an evolution of the European integration toward a "new type of federalism" 30 , intersecting and overlapping jurisdictions, or a new "neo-federalism", or "federalism without dividing competencies" ${ }^{31}$, based on multilevel governance.

For the local and regional actors, the multilevel governance model allows a better consideration of their autonomy, either into the European area, thorough their emergency in the decisional process and in the process of the implementation of the Community norms and rules, and internally, associating the subnational authorities to adopt national positions in European affairs. If at European level the local and regional powers are more instrumentalized in the benefit of a better operation of the Community legal order, that presumes their minimal involvement, through procedures often informal, the essential contribution of the principles on which is based the multilevel governance is to allow a closer situation for the subnational entities ${ }^{32}$.

The governance model developed at European level has definitely an exciting effect. It proposes methods, institutions, ideas, good practices that the actors of the process must apply in various national contexts. It is a massive transfer of "forms" that, in time, through adaptative measures, shall create also the necessary "fund", that means a radically decentralized society, where the govern is only one of its numerous actors ${ }^{33}$. Beyond its Community size, multilevel governance assumption as a way of organizing public powers at national level depends, in a certain way, by the existence of domestic pre-conditions ${ }^{34}$ : to reach a certain degree of administrative decentralization and the opening of the national government toward the ideas of partnership, dialogue, collaboration with various social actors; the existence of a powerful civil society, involved politics; the level of transparency of the decisional process.

and that it shal take as reference the White Paper to evaluate its implementation and to monitor it inside the European Union".

${ }^{27}$ The Regions Committee, The $9^{\text {th }}$ session of the CIVEX Commission, 6 June 2011, Orientation document regarding the creation of an European culture of multilevel governance: initiatives following the White Paper of the Regions Committee, Rapporteur: Luc Van Den Brande (CdR 147/2011).

${ }^{28}$ See O. Borraz, V. Guiraudon, Introduction/Comprendre les évolutions de l'action publique, in O. Borraz, V. Guiraudon (coord.), Politiques publiques 1, La France dans la gouvernance européenne, Presses de Sciences Po, Paris, 2008.

${ }^{29}$ L. Malo, Autonomie locale et Union europeenne, Ed. Bruylant, Bruxelles, 2010, p. 180.

${ }^{30}$ L. Hooghe, G. Marks, Unraveling the Central State, But How? Political Science Serie no. 87, Instutut für Höheres Studien, Wien, 2003.

${ }^{31}$ N. Levrat, Esquisse d'un néo-fédéralisme européen, in P. Grigoriou, L'Europe Unie et sa Fédéralisation, Athènes - Bruxelles, Sakkoulas \& Bruylant, 2009, pp. 31-44.

${ }^{32}$ L. Malo, op. cit., p. 198.

${ }^{33}$ M. Munteanu, op. cit.

${ }^{34}$ C. Chiriac, Emergența modelului guvernanței multilevel in România, Transilvanian Review of Administrative Sciences 1 (23)/2009, p. 10. 


\section{Bibliography}

Boussaguet, L., Jacquot, S., Les nouveaux modes de gouvernance: quelle nouveauté pour quelle gouvernance?, in R. Dehousse (coord.), Les politiques européennes, Presses de Sciences-po, Paris, 2009.

Chiriac, C., Emergența modelului guvernanței multilevel in România, Transilvanian Review of Administrative Sciences1 (23)/2009.

Levrat, N., Une dynamique multi directionnelle de la gouvernance multi-niveaux, in Les Cahiers du Comité des Régions, Vol. I, 2009.

Zielonka, J., Plurilateral Governance in the Enlarged European Union, JCMS 2007, Volume 45, number 1.

Marcou, G., La gouvernance: innovation conceptuelle ou artifice de présentation?, in La gouvernance territoriale, Annuaire des collectivités locales, 2006.

Munteanu, M., Guvernanța europeană şi dinamica formulării politicilor publice in România, in "Sfera politicii” Review, no. 125, 2006.

Wallace, H., Wallace, W., Pollack, A., Elaborarea politicilor in Uniunea Europeană, Bucharest, European Institute of Romania, V ${ }^{\text {th }}$ Edition, 2006.

Bache I., Flinders, M. V., Multilevel Governance, Oxford University Press, Oxford, 2004.

Ivan, A. L., Perspective teoretice ale construcției europene, Cluj-Napoca, Ed. Eikon, 2003.

Marks, G., Structural Policy in the European Community, in Alberta Sbragia, ed., Europolitics: Institutions and Policy Making in the 'New' European Community, the Brookings Institution, Washington D.C., 1992. 